\title{
The Static Behavior of a Ship Deck Panel Made of Composite Materials
}

\author{
ELENA-FELICIA BEZNEA ${ }^{1}$ ORCID iD: 0000-0001-8398-7055, \\ NICUSOR BAROIU ${ }^{2,3 *}$ ORCID iD: 0000-0002-1334-7025, IONEL CHIRICA ${ }^{4}$ \\ ${ }^{1}$ Dunarea de Jos University of Galati, Faculty of Engineering, Department of Mechanical Engineering, 111 Domneasca Str., \\ 800008, Galati, Romania \\ ${ }^{2}$ Dunarea de Jos University of Galati, Faculty of Engineering, Department of Manufacturing Engineering, 111 Domneasca \\ Str., 800008, Galati, Romania \\ ${ }^{3}$ Research Center in Manufacturing Engineering Technology (ITCM), Dunarea de Jos University of Galati, 111 Domneasca \\ Str., 800008, Galati, Romania \\ ${ }^{4}$ SDG - Ship Design Group, 1A Luminoasa Str., 807325, Vanatori, Galati, Romania
}

\begin{abstract}
A study on the static analysis of a naval panel made of composite sandwich materials is presented. By using FEM, the modeling of a naval floor with a length of $5 \mathrm{~m}$ and a width of $2.5 \mathrm{~m}$ is performed. Two distinct cases, have been performed: the first model consists of the plate and stiffeners made of steel and the second model concerns a panel made of composite material sandwich type steel / SANFoam103 / steel, and the stiffeners made of steel. A parametric study has been performed. The thickness of the steel faces have $6 \mathrm{~mm}$, and for the core of SANFoam have been selected the thicknesses $5 \mathrm{~mm}, 10 \mathrm{~mm}, 20 \mathrm{~mm}, 40 \mathrm{~mm}$.
\end{abstract}

Keywords: static analysis, ship deck panel, FEM analysis, composite materials, sandwich

\section{Introduction}

Composites represent the most important material used to build performing structures in all industrial domains. The basic feature of composite materials is the high strength/weight ratio, which makes them more efficient than some of the best steel categories. A sandwich panel made of composite materials is performant if it has thin and rigid faces with high strength, and the core has low density.

Sandwich panels with metal faces and foam cores are very often used as lightweight structures in shipbuilding applications [1-5], especially because of their performance on light weight and high rigidity. In the shipbuilding industry, the application of polymeric sandwich-type composites is constantly evolving, introducing into their composition new basic materials such as: fibers, resins, adhesives, cure accelerators, additives, etc.

As an alternative to panels with a classic stiffened metal structure [6-8], sandwich structures justify their use in the shipbuilding, making these materials less complex, eliminating the need for secondary stiffening (stiffeners). At the same time, other advantages of sandwich-type composite materials are related to corrosion resistance, increased tensile strength, for easier durability, and thermal insulation [9, 10].

The faces of sandwich panels can be made of metal materials (aluminum alloys or stainless steel), non-metallic (polymeric laminates with glass fibers or carbon fibers), various composite materials (reinforced polymeric) or hybrid. The core consists of a light, porous or non-porous material, granulated or special types, consisting of cells (honeycomb type) - [19] or profiles (U, I, T, etc.). As a rule, the core is a composite material that, at a long time load, slowly deforms.

As an alternative solution in shipbuilding, the concept of SPS (sandwich plate system) material has developed. This material allows the replacement of the classic panels with a stiffened steel structure with a polyurethane elastomer [5, 11-14].

In the case of naval decks, in the classical system, longitudinal structures are used as stiffening elements, whose welded joints are the sensible to corrosion and fatigue.

*email: Nicusor.Baroiu@ugal.ro 
In the case of SPS, the space between two steel plates is filled with an elastomer and thus the need for longitudinal welds on the coating is eliminated. In the case of decks repair, the process is much simplified, the main stiffeners (currents, longitudinal or transverse frames) are welded, and the remaining spaces are stiffened with elastomer, with an important financial and time advantage versus the classical methods.

In order to obtain answers such as stresses and strains for various cases of loading, of the natural vibration modes or of behavior of the structural elements to the buckling in the structural analyses that are applied in the ship structures, analytical calculations or the finite elements method are often used [15-18]. In general, in order to correctly define a structural analysis, various stages are taken, starting from the setting of objectives, type and size of the analysis, modeling of the structure and boundary conditions, modeling itself and evaluation of the results. In certain cases, linear analyses of ship structures are often sufficient.

In the work a study on the static analysis of a ship deck structure made of sandwich-type composite materials, by using the FEM is performed.

\section{Materials and methods}

\subsection{Materials}

The ship deck structure has length of $5 \mathrm{~m}$ and a width of $2.5 \mathrm{~m}$. Two cases are considered: a first case in which the floor and stiffeners are made entirely of steel, and the second where the deck panel is made of steel / SANFoam103 / steel sandwich composite material and the stiffeners are of steel. The thickness of the steel faces is $6 \mathrm{~mm}$, and the core of SANFoam has thicknesses of $5 \mathrm{~mm}, 10 \mathrm{~mm}, 20 \mathrm{~mm}$, $40 \mathrm{~mm}$ respectively.

The dimensions are chosen so that the weights of the resulting structures are approximately the same with the initial one. In the case of analysis of the static behaviour of a ship deck panel using FEM, when defining the geometry of the model, for the steel panel and stiffeners, steel is considered as materials used in modeling, steel having the characteristics of Figure 1.

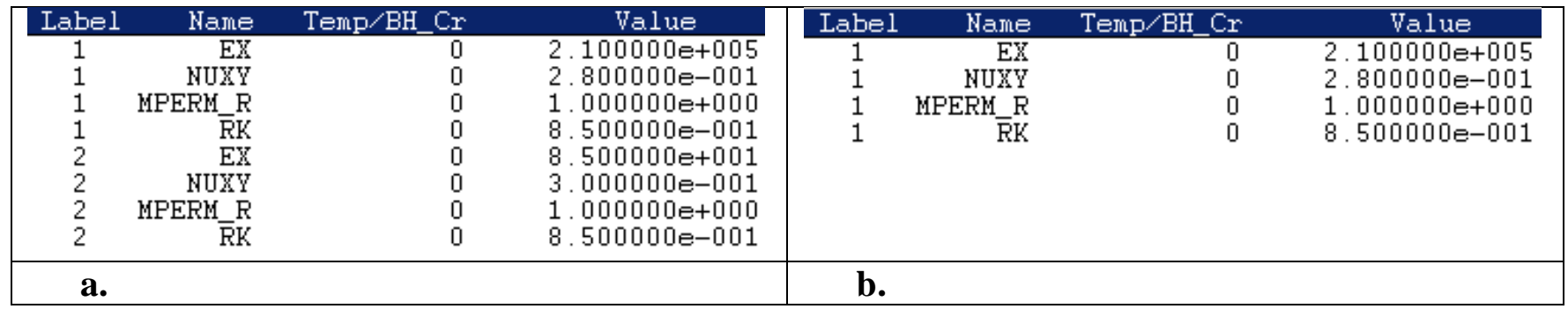

Figure 1. The characteristics of the steel used in FEM analysis: a. - panel; b. - stiffeners

The core of the sandwich is SAN Foam whose characteristics are presented in Table 1.

Table 1. SAN Foam $103 \mathrm{~kg} / \mathrm{m}^{3}$ characteristics

\begin{tabular}{|c|c|c|}
\hline Characteristics & Value & Measure unit \\
\hline Density & 103 & $\mathrm{~kg} / \mathrm{m}^{3}$ \\
\hline Elastic Isotrop & - & - \\
\hline Young's Modulus & 85 & $\mathrm{MPa}$ \\
\hline Poisson ratio & 0.3 & - \\
\hline Bulk modulus & 70.833 & $\mathrm{MPa}$ \\
\hline Shearing Modulus & 32.692 & $\mathrm{MPa}$ \\
\hline
\end{tabular}

The analyzed cases have been described in Table 2 . 
Table 2. Analysed models

\begin{tabular}{|c|c|c|c|c|}
\hline Model & \multicolumn{2}{|r|}{ Material } & Thickness [mm] & Mass [kg] \\
\hline M1 & \multicolumn{2}{|r|}{ Steel } & 12 & 1179 \\
\hline \multirow{3}{*}{ M2 } & Face1 & Steel & 6 & \multirow[t]{3}{*}{1185.4} \\
\hline & Core & SAN Foam $103 \mathrm{~kg} / \mathrm{m}^{3}$ & $\frac{0}{5}$ & \\
\hline & Face 2 & Steel & 6 & \\
\hline \multirow[t]{3}{*}{ M3 } & Face 1 & Steel & 6 & \multirow[t]{3}{*}{1191.87} \\
\hline & Core & SAN Foam $103 \mathrm{~kg} / \mathrm{m}^{3}$ & 10 & \\
\hline & Face 2 & Steel & 6 & \\
\hline \multirow[t]{3}{*}{ M4 } & Face 1 & Steel & 6 & \multirow[t]{3}{*}{1204} \\
\hline & Core & SAN Foam $103 \mathrm{~kg} / \mathrm{m}^{3}$ & 20 & \\
\hline & Face 2 & Steel & 6 & \\
\hline \multirow[t]{3}{*}{ M5 } & Face 1 & Steel & 6 & \multirow[t]{3}{*}{1230.5} \\
\hline & Core & SAN Foam $103 \mathrm{~kg} / \mathrm{m}^{3}$ & 40 & \\
\hline & Face 2 & Steel & 6 & \\
\hline
\end{tabular}

The structure of the ship deck panel (Figure 2) was modeled using COSMOS/M, static analysis: extensive library of 1D, 2D and 3D elements supports isotropic, orthotropic, anisotropic, multi-layer composite materials, and temperature-dependent material properties. Capabilities include linear gap/contacts, stress stiffening, sub-structuring, multi-point constraints, constraint equations and much more.
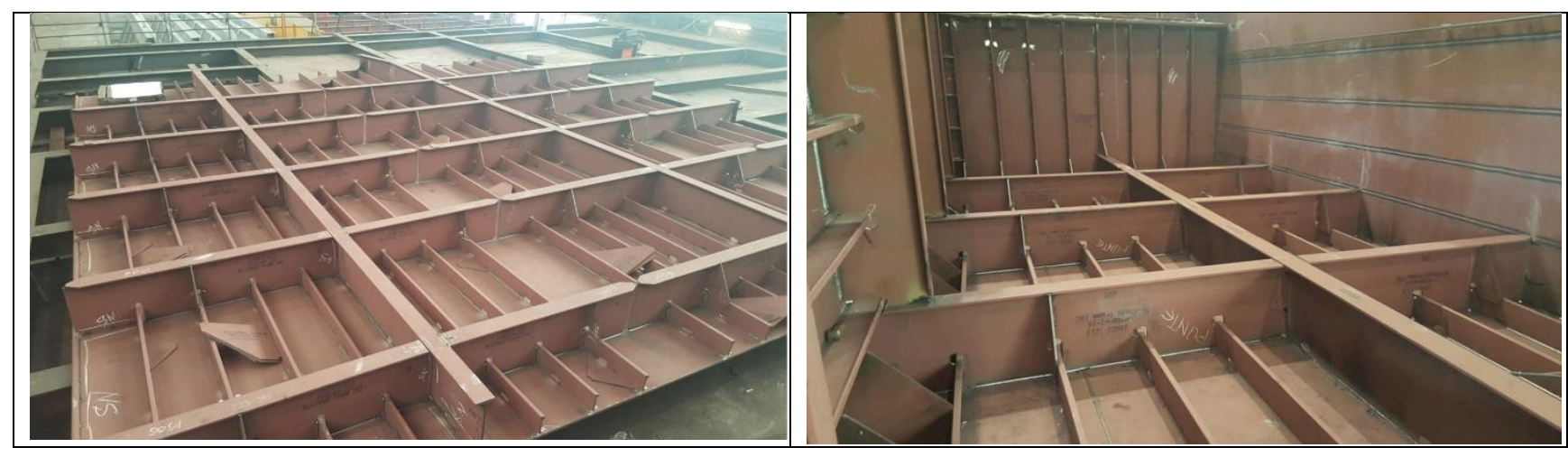

Figure 2. Ship deck panel structure

\subsection{Methods}

For the structure FEM models SHELL 4L elements are used. In Figures 3, 4 and 5 the steps of FEM model defining are presented.

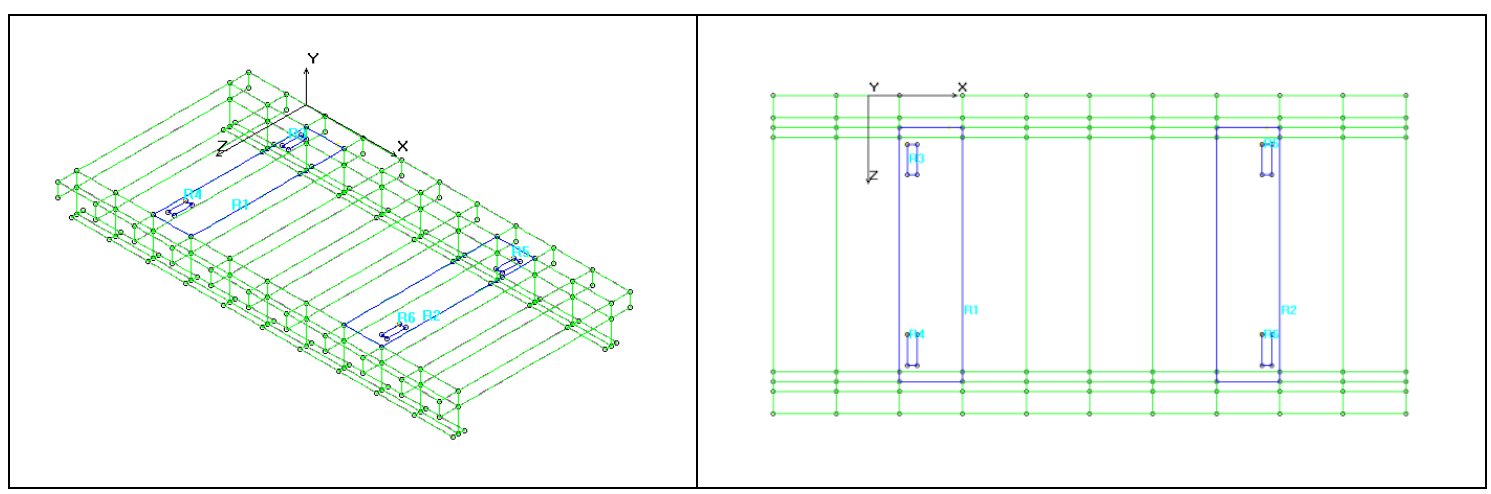

Figure 3. Ship deck structure geometry: regions defining 


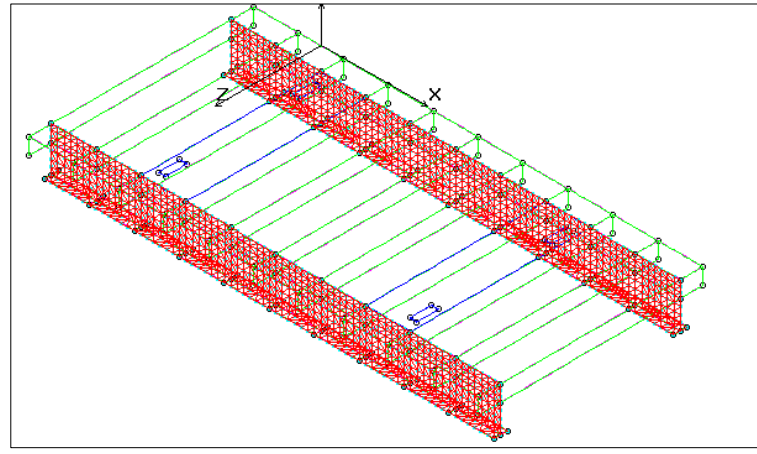

Figure 4. FEM model of transverses

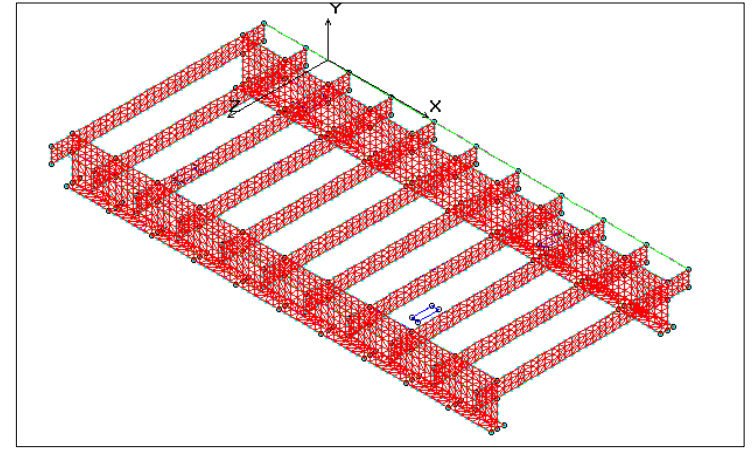

Figure 5. FEM model of longitudinals

In Figure 6 the FEM model of the deck panel structure is presented.
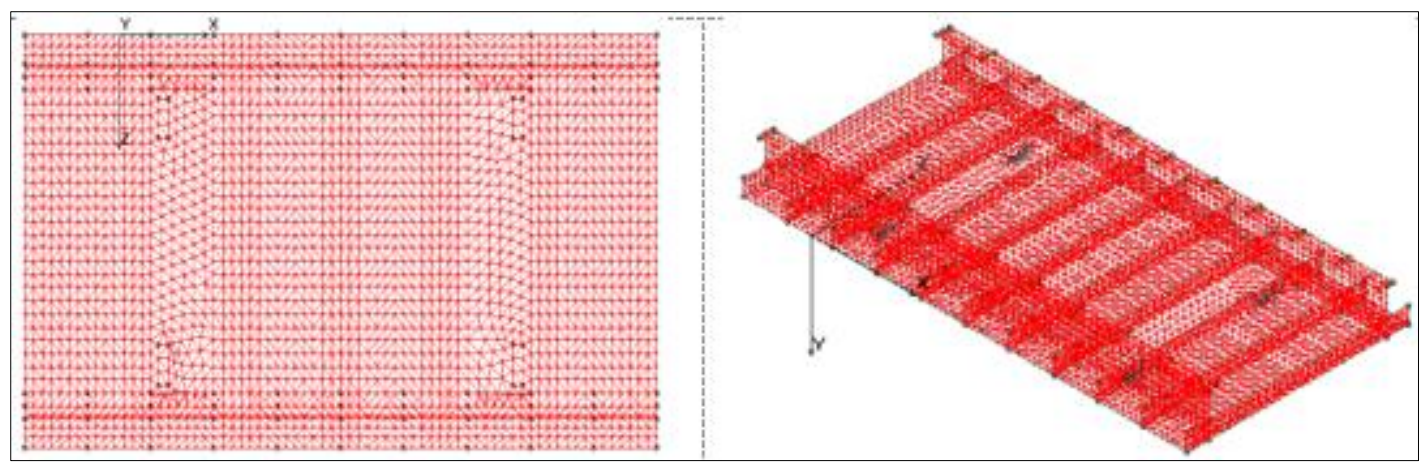

Figure 6. FEM model of the deck structure

The ship deck pane model is simple supported on all sides. The loading is produced by the tires pressure of the vehicles having the masses $1.5 \mathrm{t}, 2 \mathrm{t}, 2.5 \mathrm{t}, 3 \mathrm{t}$ and $3.5 \mathrm{t}$, as are presented in the Table 3 .

Table 3. Loads acting on the ship deck panel

\begin{tabular}{|c|c|c|}
\hline Case & Mass, $\boldsymbol{m}$ [tons] & Pressure, $\boldsymbol{p}\left[\mathbf{N} / \mathbf{m m}^{\mathbf{2}}\right]$ \\
\hline M1 & $\mathrm{m} 1=1.5$ & 0.195 \\
\hline M2 & $\mathrm{m} 2=2$ & 0.26 \\
\hline M3 & $\mathrm{m} 3=2.5$ & 0.32 \\
\hline M4 & $\mathrm{m} 4=3$ & 0.39 \\
\hline M5 & $\mathrm{m} 5=3.5$ & 0.45 \\
\hline
\end{tabular}

According to calculus of contact area of the tire car placed on the ship deck panel, the resulted pressure $(\mathbf{m} 1 \div \mathbf{m 5})$ is presented in the Table 3. In Figures 7 and 8, the boundary conditions of the ship deck panel model are illustrated. The real contact area is an ellipse, but in FEM calculus was approximated with a rectangle. 


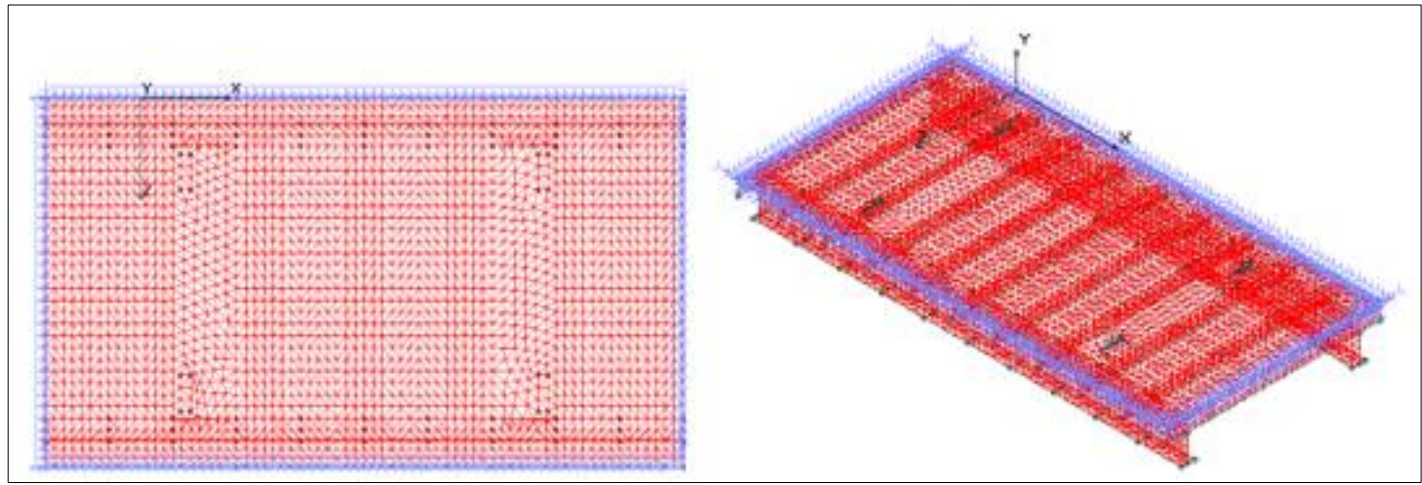

Figure 7. Boundary conditions of the panel model
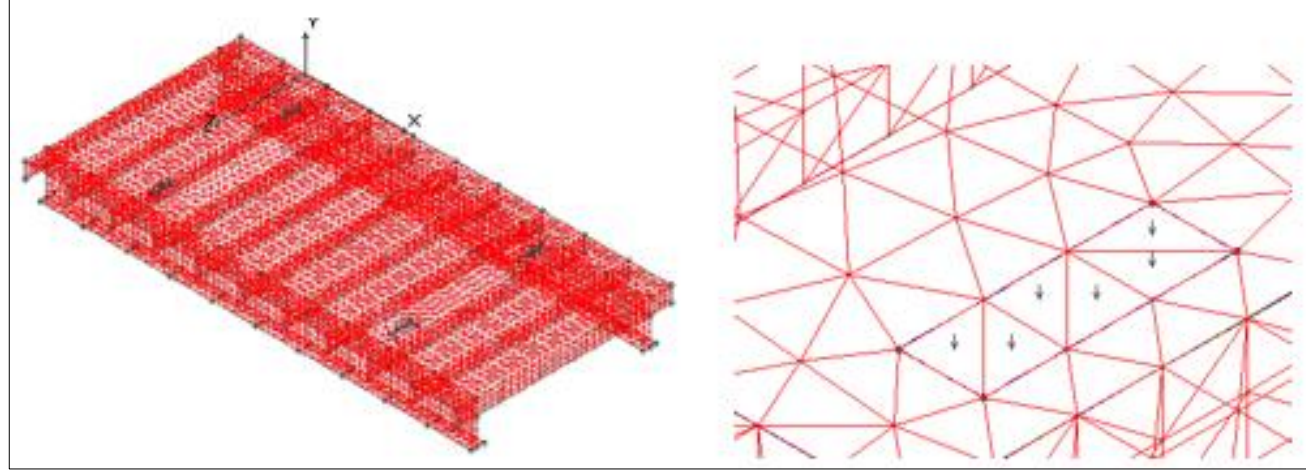

Figure 8. Details of the model loading conditions

\section{Results and discussions}

\subsection{Results}

According to the FEM analysis of the ship deck panel, the results obtained for the all five models $\mathbf{M 1} \div \mathbf{M 5}$ and five analysed cases $(\mathbf{m} \mathbf{1} \div \mathbf{m 5})$ are illustrated in the Figures $9 \div 13$.

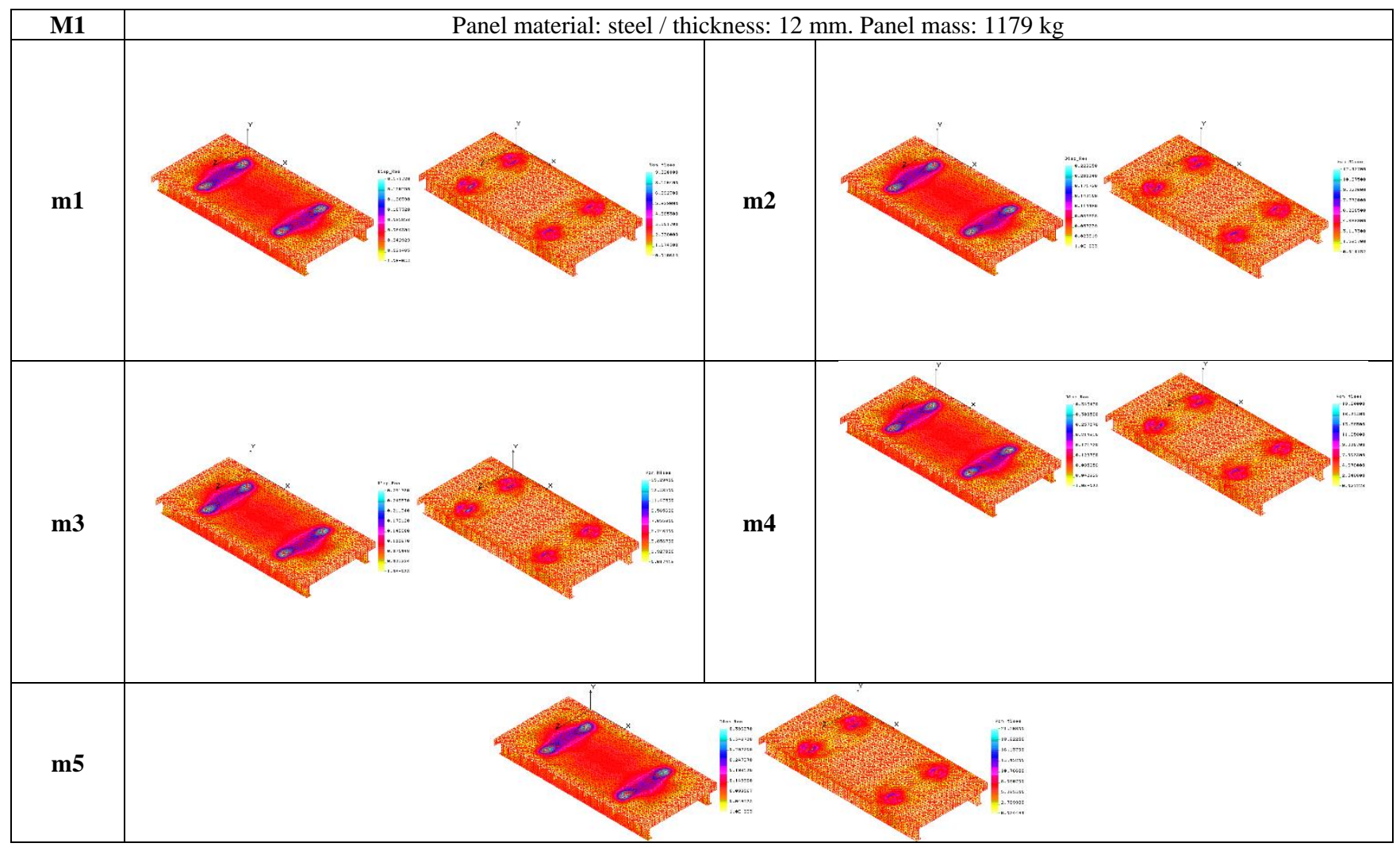

Figure 9. Model M1 - displacements map [mm] and equivalent stresses map [MPa] 


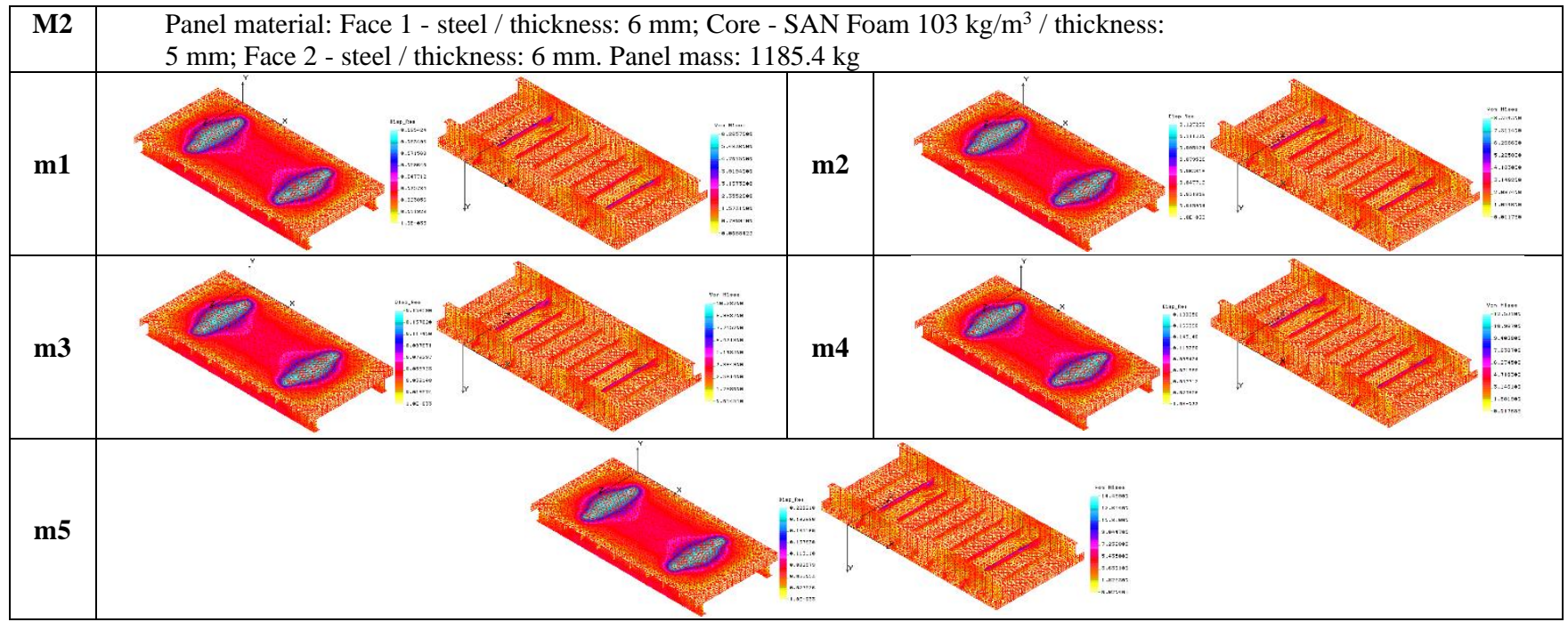

Figure 10. Model M2 - displacements map [mm] and equivalent stresses map [MPa]

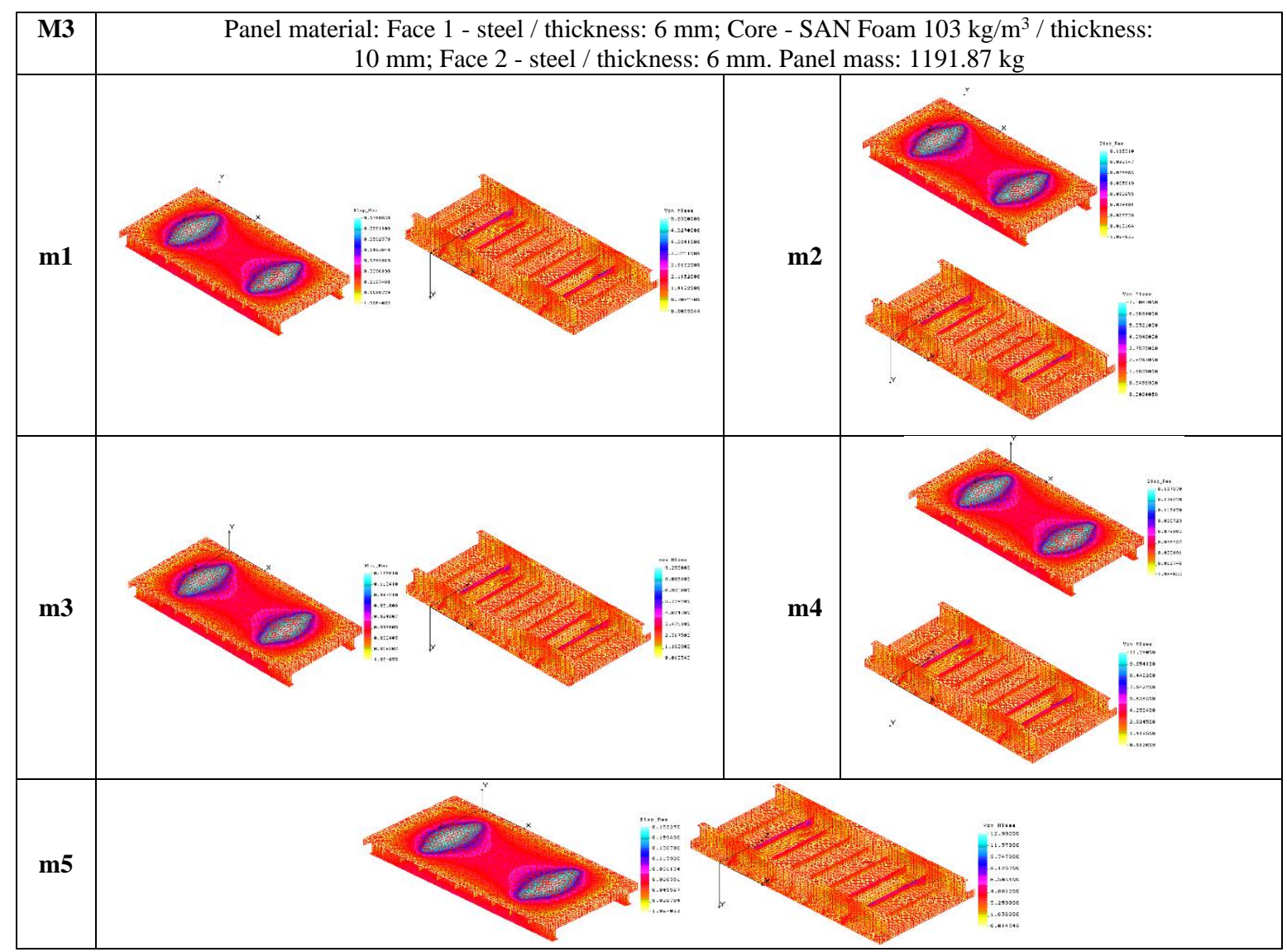

Figure 11. Model M3 - displacements map [mm] and equivalent stresses map [MPa] 


\begin{tabular}{|l|c|c|c|c|}
\hline M4 Panel material: Face 1 - steel / thickness: $6 \mathrm{~mm}$; Core - SAN Foam $103 \mathrm{~kg} / \mathrm{m}^{3} /$ thickness: \\
$20 \mathrm{~mm}$; Face 2 - steel / thickness: $6 \mathrm{~mm}$. Panel mass: $1204 \mathrm{~kg}$
\end{tabular}

Figure 12. Model M4 - displacements map [mm] and equivalent stresses map [MPa]

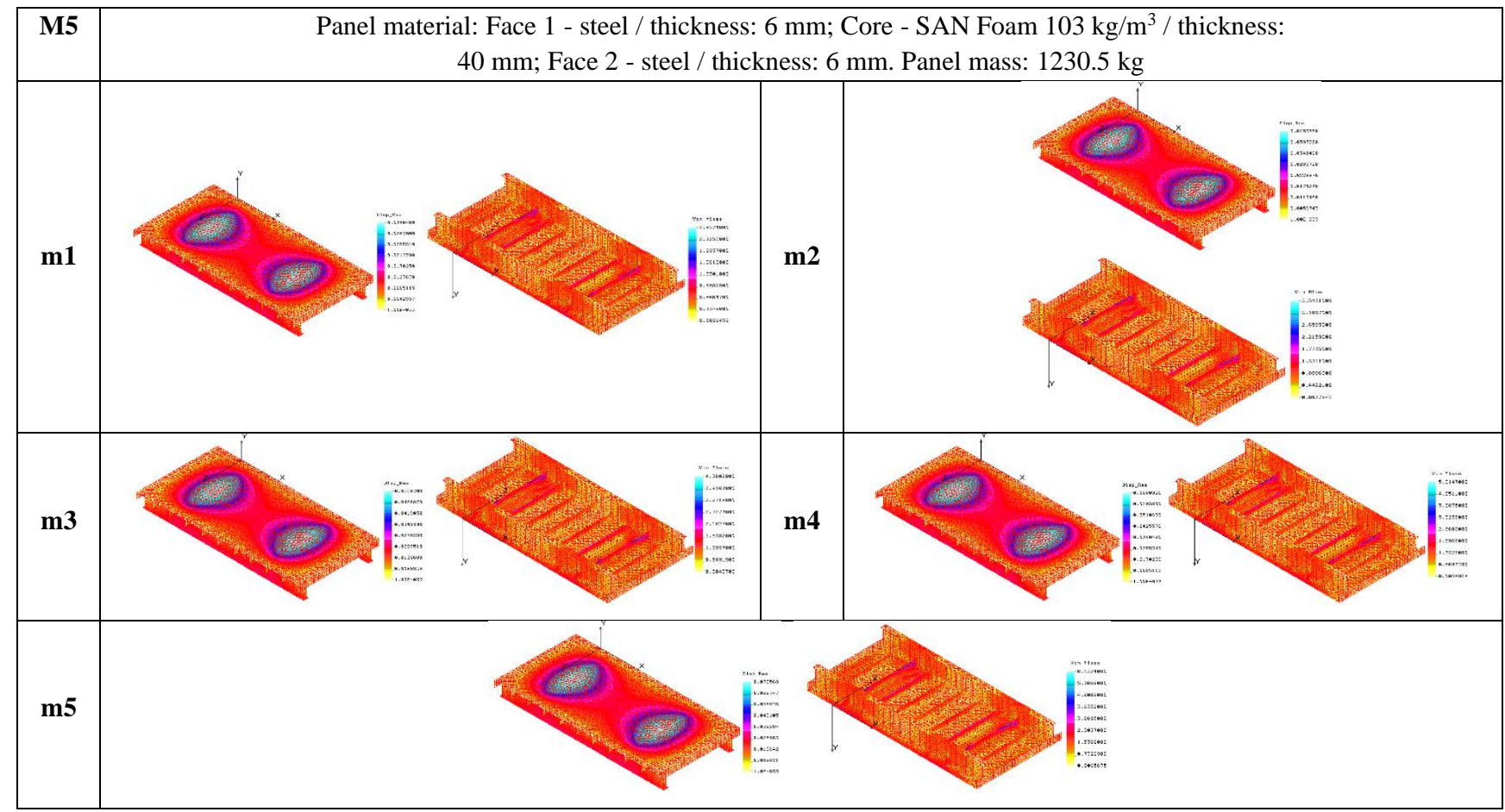

Figure 13. Model M5 - displacements map [mm] and equivalent stresses map [MPa]

\subsection{Discussions}

In the case of the deck panel made of steel (M1) it can be seen that with the increase of the mass of the vehicle, the value of the maximum displacement increases, but also increase the values of the equivalent stresses, as are illustrated in Figure 14. 


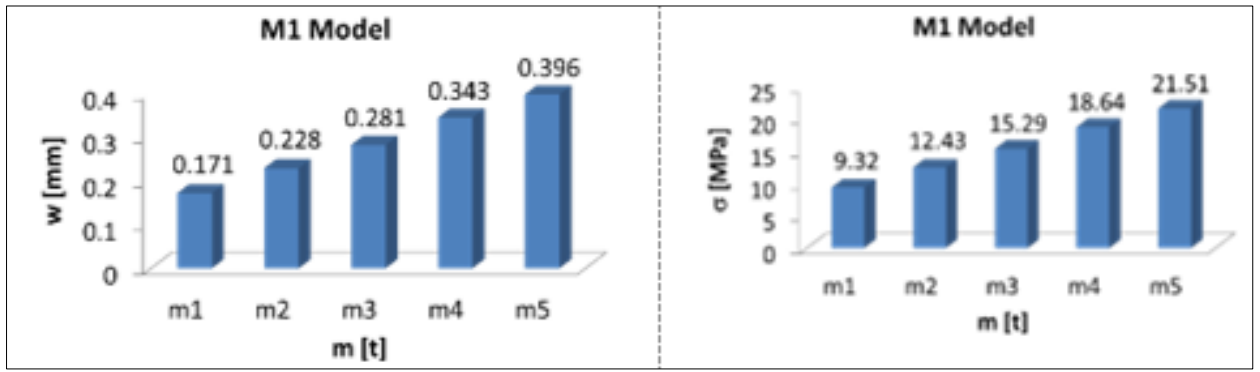

Figure 14. Model M1 - influence of mass on maximum displacements and equivalent stresses

In the case of the other models of the deck panel made of sandwich composite material with a core thickness of $5 \mathrm{~mm}$ (M2), $10 \mathrm{~mm}$ (M3), $20 \mathrm{~mm}$ (M4) and $40 \mathrm{~mm}$ (M5) and steel faces of 6mm, it can be seen that since the mass of the vehicle increases, the value of the maximum displacement also increases. The same can be seen in the case of the equivalent stress (Figures $15 \div 18$ ).

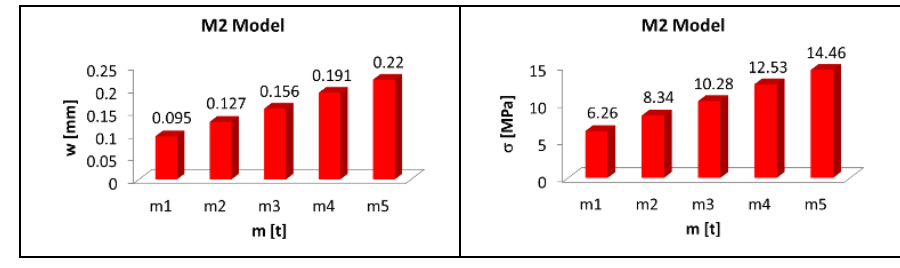

Figure 15. Model M2 - influence of mass on maximum displacements and equivalent stresses
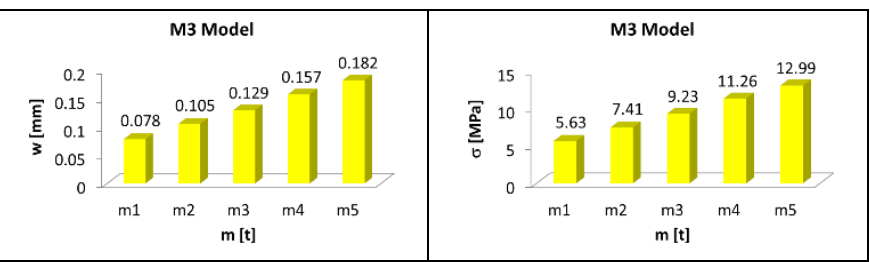

Figure 16. Model M3 - influence of mass on maximum displacements and equivalent stresses

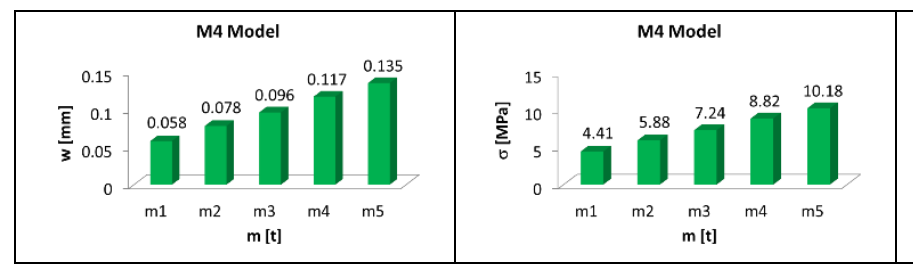

Figure 17. Model M4 - influence of mass on maximum displacements and equivalent stresses
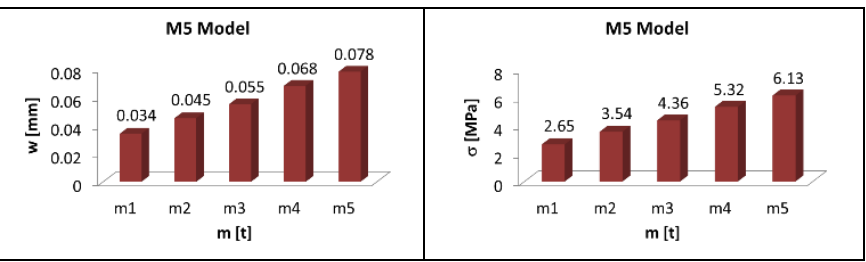

Figure 18. Model M5 - influence of mass on maximum displacements and equivalent stresses

If the forces produced by the vehicle masses $(\mathbf{m 1}, \mathbf{m} \mathbf{2}, \mathbf{m 3}, \mathbf{m 4}, \mathbf{m 5})$, are applied to the deck panel, but the thickness of the sandwich core varies, it can be seen that the maximum displacement decreases with the increase of this thickness. The same situation can be seen in the case of the equivalent stress

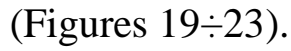

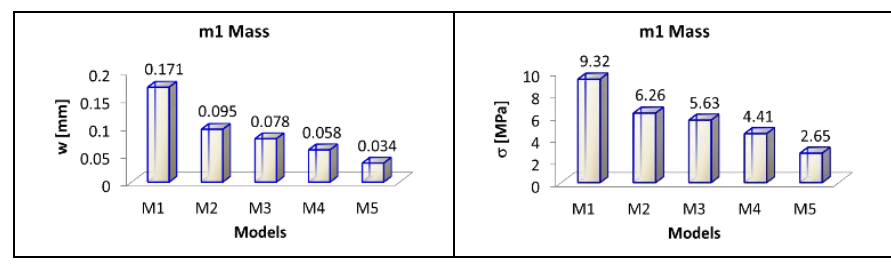

Figure 19. Models M1 $\div$ M5 - influence of mass $\mathbf{m} 1$ on maximum displacements and equivalent stresses
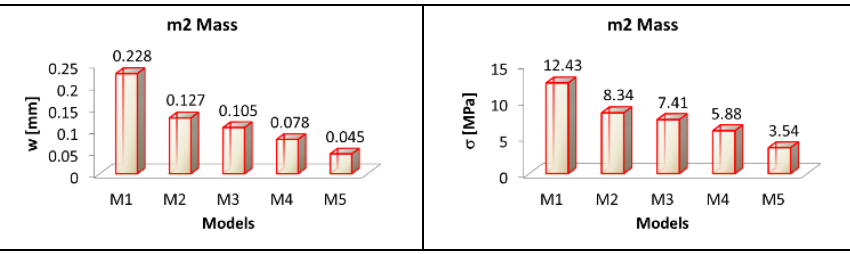

Figure 20. Models M1 $\div$ M5 - influence of mass $\mathbf{m} \mathbf{2}$ on maximum displacements and equivalent stresses 


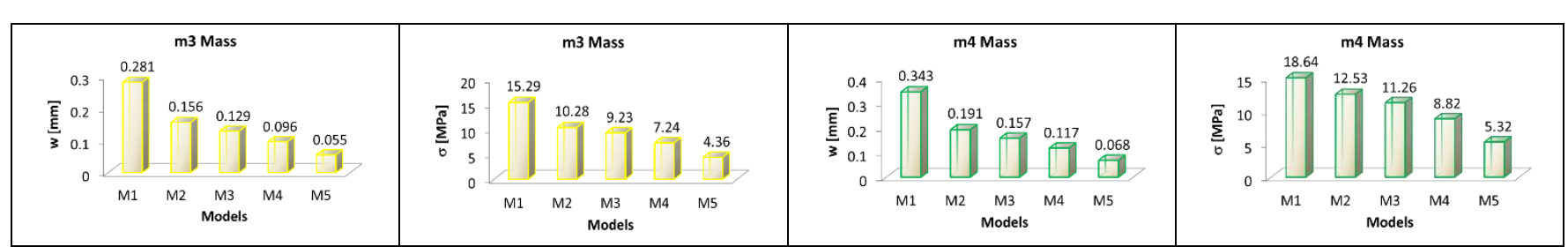

Figure 21. Models M1 $\div$ M5 - influence of mass

$\mathbf{m 3}$ on maximum displacements and equivalent stresses

Figure 22. Models M1 $\div$ M5 - influence of mass m4 on maximum displacements and equivalent stresses

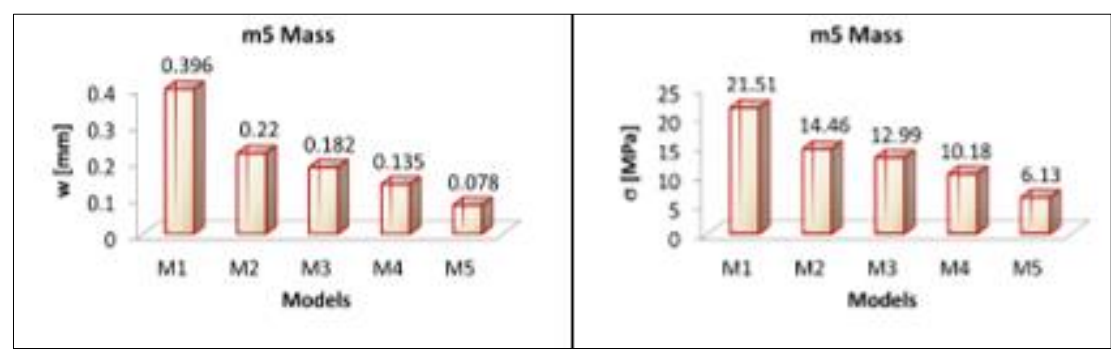

Figure 23. Models M1 $\div$ M5 - influence of mass $\mathbf{m 5}$ on maximum displacements and equivalent stresses

\section{Conclusions}

In the case of the deck panel made of sandwich composite material with a core thickness that varies between $5 \mathrm{~mm}$ and $40 \mathrm{~mm}$ and the steel faces of $6 \mathrm{~mm}$, it can be seen that with the increasing of forces produced by the vehicle masses, the value of the maximum displacement increases (e.g. from $0.095 \mathrm{~mm}$ (model M2, mass m1) to $0.22 \mathrm{~mm}$, (model M2, mass m5)) (Figure 24).

Similarly, in the case of the deck panel made of sandwich composite material with a core thickness that varies between $5 \mathrm{~mm}$ and $40 \mathrm{~mm}$ and the steel faces of $6 \mathrm{~mm}$, it can be seen that with the increasing of forces produced by the vehicle masses, the value of the equivalent stress (e.g. from $2.65 \mathrm{MPa}$ (model M5, mass m1) to 6.13 MPa, (model M5, mass m5)) (Figure 25).

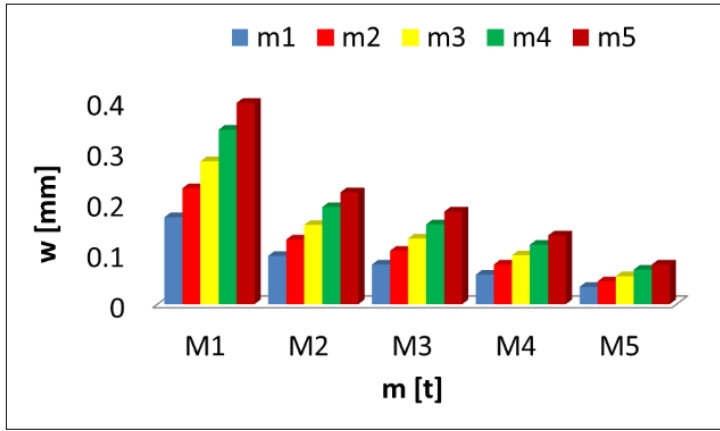

Figure 24. Models M1 $\div$ M5 - influence of mass on the maximum displacement

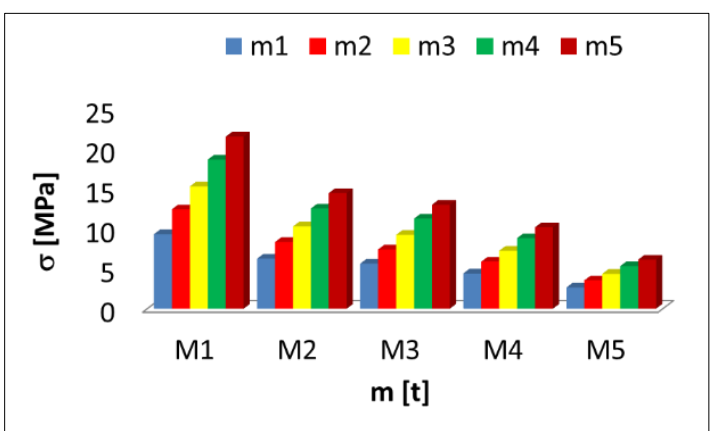

Figure 25. Model $s \mathrm{M} 1 \div \mathrm{M} 5$ - influence of mass on the maximum equivalent stress

If a single mass type is applied to the ship deck panel, but the thickness of the core of the sandwich composite varies, it can be seen that the maximum displacement decreases with the increase of core thickness, the lowest displacement value, $0.034 \mathrm{~mm}$, being recorded in the case of the model M5 - deck material: face 1 - steel with a thickness of $6 \mathrm{~mm}$, core - SAN Foam $103 \mathrm{~kg} / \mathrm{m}^{3}$ with a thickness of 40 $\mathrm{mm}$, face 2 - steel with a thickness of $6 \mathrm{~mm}$, at a load produced by the $\mathbf{m} \mathbf{1}$ mass of the vehicle $(1.5 \mathrm{t})$ (Figure 26).

Similarly, if a single mass type is applied to the ship deck panel, but the thickness of the core of the composite sandwich varies, it can be seen that the equivalent stress decreases with the increase of core thickness, recording a minimum value of $2.65 \mathrm{MPa}$ (model M5, mass m1) (Figure 27). 


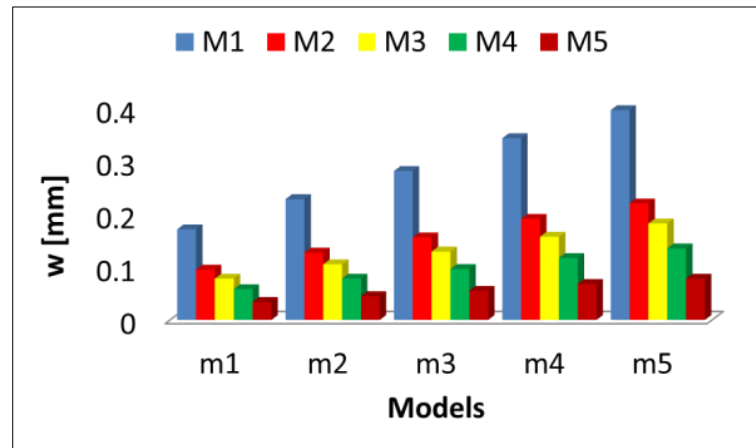

Figure 26. Masses $\mathrm{m} 1 \div \mathrm{m} 5$ - influence of the case model on the maximum displacement

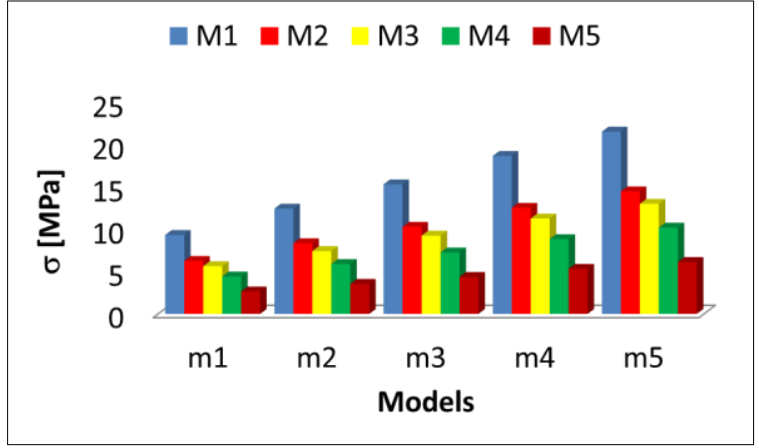

Figure 27. Masses $\mathrm{m} 1 \div \mathrm{m} 5$ - nfluence of the case model on the maximum equivalent stress

Even in these upper conditions, both in the case of displacements and equivalent stresses obtained by FEM modeling, it is observed that the highest values of displacements and stresses are recorded on the ship deck panel made of steel, with a thickness of $12 \mathrm{~mm}$, these varying upwards with the increase in the values of the loading, which demonstrates that the composite panels have a better behavior compared to the metal ones, even if their weight is approximately equal. This observation is provided by the metal stiffeners, which exist in all the analyzed constructive models.

\section{References}

1.BRAGAGNOLO, G., CROCOMBE, A.D., OGIN, S.L., MOHAGHEGHIAN, I., SORDON, A., MEEKS, G., SANTONI, C., Investigation of skin-core debonding in sandwich structures with foam cores, Mater Design, 186, 2020, 1-10.

2.ARDHYANANTA, H., SARI, E.N., WICAKSONO, S.T., ISMAIL, H., TUSWAN, T., ISMAIL A., Characterization of vinyl ester bio-resin for core material sandwich panel construction of ship structure application: Effect of palm oil and sesame oil, AIP Conference Proceedings, 2202, 2019, 1-5.

3.BIRMAN, V., KARDOMATEAS, G.A., Review of current trends in research and applications of sandwich structures, Compos Part B-Eng, 142, 2018, 221-240.

4.BEZNEA, E.F., CHIRICĂ, I., BAROIU, N., TEODOR, V.G., Parametric study of experimental and numerical simulation of sandwich composite structures flexural behaviour, Mater. Plast., 54(4), 2017, 682-688.

5.RAMAKRISHNAN, K.V., SUNIL KUMAR G., Applications of Sandwich Plate System for Ship Structures, IOSR-Journal of Mechanical and Civil Engineering, 2016, 83-90.

6.FAIDZI, M.K., ABDULLAH, S., ABDULlAH, M.F., AZMAN, A.H., HUI, D., SINGH, S.S.K., Review of current trends for metal-based sandwich panel: Failure mechanisms and their contribution factors, Engineering Failure Analysis, 123, 2021, https://doi.org/10.1016/j.engfailanal.2021.105302.

7. KUJALA, P., KLANAC, A., Steel sandwich panels in marine applications, Brodogradnja, 56(4), 2005, 305-314.

8.KONG, C.W., NAM, G.W., JANG, Y.S., YI, Y.M., Experimental strength of composite sandwich panels with cores made of aluminum honeycomb and foam, Adv Compos Mater, 23, 2014, 43-52.

9.BAROIU, N., BEZNEA, E.F., COMAN, G., CHIRICĂ, I., Static and thermal behaviour of ship structure sandwich panels, Therm Sci, 25(2A), 2021, 1109-1121.

10. BEZNEA, E.F., BAROIU, N., COMAN, G., CHIRICĂ, I., Influence of the thermal field on static behaviour of sandwich structures, Mater. Plast., 56(1), 2019, 110-114.

11.MOMČILOVIĆ, N., MOTOK, M., Estimation of Ship Lightweight Reduction by Means of Application of Sandwich Plate System, FME Transactions, 37, 2009, 123-128.

12. XUE, Q., ZHANG, C., ZOU, G., WANG, Y., Buckling Analysis of Sandwich Plate Systems with Stiffening Ribs: Theoretical, Numerical and Experimental Approaches, Advances in Civil Engineering, 2019, 1-14, https://doi.org/10.1155/2019/8737561. 
13.BALIKOĞLU, F., DEMIRCIOĞLU, T.K., YILDIZ, M., ARSLAN, N., ATAŞ, A., Mechanical performance of marine sandwich composites subjected to flatwise compression and flexural loading: Effect of resin pins, J Sandw Struct Mater, 22(6), 2020, 2030-2048.

14.GOPICHAND A., KRISHNAIAH G., REDDY D., SHANKAR V.S., Modal Analysis of a Steel Sandwich Plate System (SPS) Floor, IJERT-International Journal of Engineering Research \& Technology, 2(11), 2013, 3002-3004.

15.GALES,, C., BAROIU, N., On the bending of plates in the electromagnetic theory of microstretch elasticity, Zamm-Z Angew Math Me, 93(1), 2013, 1-17.

16.TUSWAN, T., ABDULLAH, K., ZUBAYDI, A., BUDIPRIYANTO, A., Finite-element Analysis for Structural Strength Assessment of Marine Sandwich Material on Ship Side-shell Structure, Materials Today: Proceedings, 13(1), 2019, 109-114.

17.SUJIATANTI, S.H., ZUBAYDI, A., BUDIPRIYANTO, A., Finite Element Analysis of Ship Deck Sandwich Panel, Applied Mechanics and Materials, 874, 2018, 134-139.

18.KOVÁCS, G., SZIRBIK, S., Verification of an Optimal Composite Sandwich Structure by Finite Element Analysis, International Journal of Engineering, X(3), 2012, 395-398.

19.VOICU, A.D., HADAR, A., VLASCEANU, D., TUDOSE, D.I., Vibrational Study of a Helicopter Tail Rotor Blade with Different Polymer Inner Core Materials, Mater. Plast., 57(2), 2020, 169-178.

Manuscript received: 2.11 .2021 